\title{
Assessment of the degree of illness acceptance in patients diagnosed with hepatitis $C$
}

\author{
Lidia Elżbieta Sierpińska',A-F® \\ ${ }^{1}$ Military Clinical Hospital No. 1 with Polyclinic, Independent Public Health Unit, Lublin, Poland \\ A - Research concept and design, B - Collection and/or assembly of data, C - Data analysis and interpretation, \\ $D$ - Writing the article, E-Critical revision of the article, F- Final approval of the article
}

Sierpińska LE. Assessment of the degree of illness acceptance in patients diagnosed with hepatitis C. Ann Agric Environ Med. 2022; 29(2): 224-231. doi: 10.26444/aaem/145375

\begin{abstract}
I Abstract
Introduction. In Poland, approximately 730,000 people are infected with the hepatitis C virus (HCV). Acceptance of a chronic illness may positively motivate patients in the process of treatment. The higher the degree of illness acceptance, the lower the feeling of psychological discomfort and a lower intensity of negative emotions.

Objective. The aim of the study was assessment of illness acceptance among patients with chronic hepatitis C, and determination of the level of the relationship between social and demographic variables, and the degree of illness acceptance. Materials and method. The study included 220 patients with a diagnosis of chronic hepatitis C. The research method was a diagnostic survey, while the instruments used were the Acceptance of IIIness Scale (AIS) and an author-constructed questionnaire.

Results. Respondents most frequently accepted their illness to the mean degree (30 scores), and a low category or even the lack of acceptance ( $<20$ scores) of respondents. Urban inhabitants significantly more often accepted their illness to a high degree, compared to rural inhabitants. Disability pensioners and retired pensioners significantly more frequently accepted their disease in the category - low degree. The remaining independent variables: gender, age, education, marital status, number of years of illness, had no significant effect on the degree of acceptance of hepatitis C.

Conclusions. The majority of patients diagnosed with chronic hepatitis $\mathrm{C}$ accept their illness to the mean degree. Patients with hepatitis $\mathrm{C}$ should be covered with psychological assistance in order to change the way of perception and evaluation of their health situation in more positive terms.
\end{abstract}

\section{Key words}

acceptance of illness, hepatitis C, scale AIS

\section{INTRODUCTION}

Based on the assessment of the epidemiological situation in the area of hepatitis $\mathrm{C}$ in Poland for over more than a decade, this is a serious medical and social problem in the populations of both adults and children [1,2,3]. The etiologic factor of hepatitis $\mathrm{C}$ is the hepatitis $\mathrm{C}$ virus (HCV), the only reservoir of which and the source of infection are humans [4]. HCV is transmitted through blood and proliferates (replicates), mainly in the liver cells (hepatocytes), but also in other organs, such as: spleen, pancreas, adrenal glands, brain, bone marrow, thyroid gland, lymph nodes, peripheral blood mononuclear cells (lymphocytes, monocytes, macrophages) $[5,6]$.

Based on epidemiological studies conducted in Poland during 2009-2012, it was estimated that in the population of adults the percentage of those infected with $\mathrm{HCV}$ was $0.95-1.9 \%$. In turn, an active infection with HCV diagnosed based on the presence of HCV - RNA was detected in $0.6 \%$ of the examined people (approx. 200,000 cases of infection) [7, 8]. It should be emphasized that the number of those infected with $\mathrm{HCV}$ is difficult to estimate, mainly due to the fact that many people are unaware that they have the disease.

The vast majority of patients contract hepatitis $\mathrm{C}$ in association with medical procedures performed in treatment

Address for correspondence: Lidia Elżbieta Sierpińska, Military Clinical Hospital No. 1 with Polyclinic, Independent Public Health Unit, Al. Racławicke 23, 20-049 Lublin, Poland

E-mail: sierpinska1@wp.pl

Received: 04.03.2021; accepted: 28.12.2021; first published: 10.01.2022 facilities $[2,9,10]$. Most often, the risk of infection is created as a consequence of the transfusion of blood and/or blood products, and organ transplantation (before 1992), endoscopy procedures, haemodialysis, intravenous injections, and dental treatments $[11,12]$. Based on the first screening study in Poland, carried out in 1994 for the presence of anti-HCV antibodies in blood donors, it was found that $1.4 \%$ of blood donors had a positive result [13].

Hepatitis $C$ is a chronic disease, and when untreated may lead to cirrhosis of the liver and/or hepatocellular carcinoma $[14,15$, $16,17,18,19]$. An important problem in the course of the disease is the degree of its acceptance. A high degree of acceptance is associated, among other things, with a frequent selection of prohealth behaviours which result in better results of treatment of the disease, also with the maintenance of a proper diet, and maintaining a better psychological condition. Health attitudes in these areas may postpone the risk of development of cirrhosis or even exclude this risk. The whole process of changes aimed at the restoration of balance and feeling of control of own life contributes to the acceptance of the illness.

\section{OBJECTIVE}

The aim of the study was assessment of the degree of acceptance of the illness among patients with chronic hepatitis $\mathrm{C}$, and determination of the level of the relationship between the selected social and demographic variables, and the degree of illness acceptance. 


\section{MATERIALS AND METHOD}

The study comprised a group of 220 patients infected with $\mathrm{HCV}$ at different times. The respondents were aged 18-87. In the study group the percentage of females was higher than that of males (52.3\% and $47.7 \%$, respectively).

The selection of respondents for the study was purposeful. Due to organizational difficulties with reaching out to persons who had a diagnosis of hepatitis $\mathrm{C}$, including the reluctance to disclose the disease, the study covered patients in medical facilities, after obtaining consent from their managers, as well as students at the Higher School in Radom, members of their families and persons from their nearest surroundings, who expressed their consent to participate in research.

The study group were patients treated in 7 hospitals located in 4 provinces: Warsaw, Lublin, Katowice, and Gdańsk. The basic criterion for qualification into the study group was hepatitis $\mathrm{C}$ confirmed by a medical examination. The study was carried out during the period from August 2014 - May 2018. Consent for the study was obtained from the academic Senate of the Higher School in Radom (No. 8/2014).

The study was conducted by the method of a diagnostic survey, and the research instruments used were a standardized author-constructed questionnaire and a standard test: the Acceptance of Illness Scale (AIS) [20]. The authors of the AIS are: B. J. Felton, T. A. Revenson and G. A. Hinrichsen, and was adopted to the Polish conditions by Z. Juczyński. The AIS is the scale for assessment of the degree of acceptance of illness by a patient: the higher the degree of illness acceptance, the lower the intensity of negative behaviours and emotions related with the disease and its treatment. The AIS consists of 8 statements concerning negative consequences of the state of health. To each statement a 5-point scale is ascribed, by which a patient may describe his/her current state of health by ticking scores: 1 - I definitely agree, $2-$ I agree, $3-$ I do not know, 4 - I do not agree, 5 - I definitely disagree. Ticking 1 score means the lack of acceptance of illness, whereas 5 scores means full acceptance of illness. The sum of scores of illness acceptance is the measure of the total scores, and remains within the range from 8 - 40 scores [21]. The higher the result, the higher the degree of acceptance of illness. Values below 20 scores were considered as a low result, the mean result remains within the range from $20-30$ scores, whereas values above 30 scores mean a high or full acceptance of illness.

The questionnaire developed for the purpose of this study also contained, among others, questions concerning sociodemographic data, such as: gender, age, education level, place of residence, marital status, and occupational activity.

The results were presented in the form of percentages and numbers. Statistical analysis was performed in order to detect possibly occurring relationships, using the non-parametric Pearson's chi-squared test. The $p$ values $<0.05$ were considered statistically significant. Mann-Whitney U test was applied to compare 2 independent groups. The relationships between the examined variables were investigated using Spearman's rank correlation coefficient.

Statistical analysis was performed by means of the statistical software StatSoft Statistica 12.0 PL, and the Microsoft Office suite.

\section{RESULTS}

The study included 220 respondents. Table 1 demonstrates thesocio-demographic characteristics of persons infected with HCV.

Table 1. Structure of respondents according to gender, age, education level, place of residence, marital status, and occupational activity, including the sources of maintenance

\begin{tabular}{|c|c|c|}
\hline INDEPENDENT VARIABLE & $\mathrm{N}$ & $\%$ \\
\hline \multicolumn{3}{|l|}{ GENDER } \\
\hline female & 115 & 52.3 \\
\hline male & 105 & 47.7 \\
\hline \multicolumn{3}{|l|}{ AGE } \\
\hline $18-35$ & 15 & 6.8 \\
\hline $36-50$ & 68 & 30.9 \\
\hline $51-65$ & 93 & 42.3 \\
\hline $66-87$ & 44 & 20.0 \\
\hline \multicolumn{3}{|l|}{ EDUCATION LEVEL } \\
\hline primary & 21 & 9.5 \\
\hline primary vocational & 84 & 38.2 \\
\hline secondary & 82 & 37.3 \\
\hline higher & 33 & 15.0 \\
\hline \multicolumn{3}{|l|}{ PLACE OF RESIDENCE } \\
\hline rural & 73 & 33.2 \\
\hline urban & 147 & 66.8 \\
\hline \multicolumn{3}{|l|}{ MARITAL STATUS } \\
\hline never married & 40 & 18.2 \\
\hline married & 109 & 49.5 \\
\hline divorced & 30 & 13.6 \\
\hline widowed & 41 & 18.6 \\
\hline \multicolumn{3}{|c|}{ OCCUPATIONAL ACTIVITY AND SOURCES OF MAINTENANCE } \\
\hline occupationally active & 88 & 40.0 \\
\hline disability pension & 87 & 39.5 \\
\hline retirement pension & 31 & 14.1 \\
\hline unemployment benefit & 8 & 3.6 \\
\hline sick leave & 3 & 1.4 \\
\hline in the course of study & 2 & 0.9 \\
\hline rehabilitation benefit & 1 & 0.5 \\
\hline
\end{tabular}

In the study group, the degree of acceptance of hepatitis $\mathrm{C}$ illness was assessed using the Acceptance of Illness Scale (AIS). The scope of the AIS, in accordance with the criteria of the standard instrument, is within the range from $8-40$ scores (Tab. 2).

The largest number of respondents declared that their degree of acceptance of illness was within the category of mean values $-20-30$ scores $(41.8 \%)$.

Table 2. Degree of acceptance of illness described by the respondents according to the AIS

\begin{tabular}{lcc}
\hline Degree of acceptance of illness (AIS) & $\mathrm{n}$ & $\%$ \\
\hline lack of acceptance or low acceptance of illness (<20 scores) & 63 & 28.7 \\
\hline mean acceptance of illness (20-30 scores) & 92 & 41.8 \\
\hline high, full acceptance of illness (>30 scores) & 65 & 29.5 \\
\hline Total & 220 & 100.0 \\
\hline
\end{tabular}


Due to the difficulties with establishing the sources of infection with hepatitis $C$ virus, the respondents were asked about their knowledge concerning the circumstances of infection with this virus. The majority $(62.7 \%)$ reported that they were unable to indicate the circumstances in which they might have become infected with HCV. The remainder, i.e. $37.3 \%$ of respondents admitted that they possessed such knowledge (Tab. 3).

Table 3. Degree of acceptance of illness according to respondents' knowledge concerning circumstances of infection with HCV

\begin{tabular}{|c|c|c|c|c|c|}
\hline \multirow{2}{*}{$\begin{array}{l}\text { Knowledge concerning circumstances of } \\
\text { infection with hepatitis } C \text { virus }\end{array}$} & & \multicolumn{3}{|c|}{ AIS result } & \multirow{2}{*}{ Total } \\
\hline & & $<20$ & $20-30$ & $>30$ & \\
\hline \multirow{2}{*}{ Yes } & $\mathrm{N}$ & 27 & 29 & 26 & 82 \\
\hline & $\%$ & 32.9 & 35.4 & 31.7 & 100.0 \\
\hline \multirow{2}{*}{ No } & $\mathrm{n}$ & 36 & 63 & 39 & 138 \\
\hline & $\%$ & 26.1 & 45.6 & 28.3 & 100.0 \\
\hline \multirow{2}{*}{ Total } & $\mathrm{n}$ & 63 & 92 & 65 & 220 \\
\hline & $\%$ & 28.6 & 41.8 & 29.6 & 100.0 \\
\hline Stat. $\left(\mathrm{Chi}^{2}\right),{ }^{\prime} p^{\prime}$ & & \multicolumn{3}{|c|}{$2.349000 ; p=0.3089$} & - \\
\hline
\end{tabular}

The largest number of respondents from the group of those who mentioned that they had knowledge concerning the circumstances which could have been the cause of infection with $\mathrm{HCV}$, described their degree of acceptance of illness within the category - mean degree of acceptance (20-30 scores) $-35.4 \%$ of this population. Also in the group of respondents who had no knowledge about the circumstances of infection with hepatitis $\mathrm{C}$ virus, similar to those who declared such knowledge, the largest number assessed their degree of illness acceptance within the mean category (20-30 scores) $-45.6 \%$.

Analysis of data showed that no significant relationship occurred between the respondents knowledge concerning circumstances of infection with $\mathrm{HCV}$, and their degree of acceptance of the illness ( $p>0.05$ ) (Tab. 3).

Based on the analysis of the collected data the types of circumstances were presented in which, in respondents' opinions, infection with HCV might have occurred (Tab. 4).

Nearly a half of respondents mentioned that the fact that infection might have taken place in a hospital (in association with a surgical procedure, conservative treatment, childbirth, organ transplantation, dialysis) $-47.6 \%$.

As many as $61.8 \%$ of the total number of respondents received treatment due to chronic hepatitis $C$.

Each patient in the study was asked about knowledge concerning the duration of hepatitis $\mathrm{C}$ disease. These data were analyzed according to the degree of acceptance of illness (Tab. 5).

The largest number of respondents mentioned that the duration of their illness was within the range from 11-20 years (39.1\%).

The data was also analyzed concerning the degree of illness acceptance according to its duration. In the sub-population of respondents who evaluated their degree of acceptance of the illness as being the lowest ( $<20$ scores), the largest number of patients reported the duration of their disease within the range $11-20$ years $-41.2 \%$. Among respondents who described their degree of illness acceptance as mean (20-30 scores), the duration of the diseases was most frequently
Table 4. Circumstances of infection with HCV in respondents' opinions.

\begin{tabular}{|c|c|c|c|c|c|}
\hline \multirow{2}{*}{ Circumstances in which HCV infection occurred } & & \multicolumn{3}{|c|}{ AIS result } & \multirow{2}{*}{ Total } \\
\hline & & $<20$ & $20-30$ & $>30$ & \\
\hline \multirow{2}{*}{$\begin{array}{l}\text { in hospital (surgical procedure, conservative } \\
\text { treatment, childbirth, organ transplantation, } \\
\text { dialysis) }\end{array}$} & $\mathrm{n}$ & 12 & 16 & 11 & 39 \\
\hline & $\%$ & 44.5 & 50.0 & 47.9 & 47.6 \\
\hline \multirow{2}{*}{$\begin{array}{l}\text { in association with blood transfusion, } \\
\text { plasmapheresis }\end{array}$} & $\mathrm{n}$ & 4 & 7 & 3 & 14 \\
\hline & $\%$ & 14.8 & 21.9 & 13.0 & 17.1 \\
\hline \multirow{2}{*}{ during dental treatment } & $\mathrm{n}$ & 2 & 2 & 3 & 7 \\
\hline & $\%$ & 7.4 & 6.2 & 13.0 & 8.5 \\
\hline \multirow{2}{*}{$\begin{array}{l}\text { occupational exposure ( } 2 \text { nurses, } 2 \text { hospital } \\
\text { orderlies) }\end{array}$} & $\mathrm{n}$ & 2 & 0 & 2 & 4 \\
\hline & $\%$ & 7.4 & 0.0 & 8.7 & 4.9 \\
\hline \multirow{2}{*}{ in association with tattoo } & $\mathrm{n}$ & 1 & 1 & 0 & 2 \\
\hline & $\%$ & 3.7 & 3.1 & 0.0 & 2.4 \\
\hline \multirow{2}{*}{ narcotic injection } & $\mathrm{n}$ & 1 & 0 & 1 & 2 \\
\hline & $\%$ & 3.7 & 0.00 & 4.4 & 2.4 \\
\hline \multirow{2}{*}{ in other circumstances } & $\mathrm{n}$ & 5 & 6 & 3 & 14 \\
\hline & $\%$ & 18.5 & 18.8 & 13.0 & 17.1 \\
\hline \multirow{2}{*}{ Total } & $\mathrm{n}$ & 27 & 32 & 23 & 82 \\
\hline & $\%$ & 32.9 & 39.0 & 28.1 & 100.0 \\
\hline
\end{tabular}

Table 5. Assessment of the degree of acceptance by respondents of hepatitis $C$ according to duration of the disease

\begin{tabular}{lccccc}
\hline \multirow{2}{*}{ Duration of disease (years) } & & \multicolumn{3}{c}{ Als result } & \multirow{2}{*}{ Total } \\
\cline { 2 - 5 } $1-5$ & & $<20$ & $20-30$ & $>30$ & \\
\hline \multirow{2}{*}{$6-10$} & $\mathrm{n}$ & 11 & 20 & 13 & 44 \\
\cline { 2 - 5 } & $\%$ & 17.5 & 21.7 & 20.0 & 20.0 \\
\hline \multirow{2}{*}{$11-20$} & $\mathrm{n}$ & 18 & 28 & 11 & 57 \\
\cline { 2 - 5 } & $\%$ & 28.6 & 30.5 & 16.9 & 25.9 \\
\hline \multirow{2}{*}{20} & $\mathrm{n}$ & 26 & 31 & 29 & 86 \\
\hline \multirow{2}{*}{ Total } & $\%$ & 41.2 & 33.7 & 44.6 & 39.1 \\
\hline & $\mathrm{n}$ & 8 & 13 & 12 & 33 \\
\hline & $\%$ & 12.7 & 14.1 & 18.5 & 15.0 \\
\hline
\end{tabular}

Stat. $($ Chi^2) , 'p' $5.324901 ; p=0.50287$

$11-20$ years (33.7\%), followed by $6-10$ years (30.5\%). Among respondents who reported that they fully accepted their illness ( $>30$ scores) the largest number mentioned the duration of the disease from $11-20$ years $-44.6 \%$ (Tab. 5)

No statistically significant differences were found between duration of the disease and level of illness acceptance ( $p>0.05)$.

The following demographic and social characteristics were adopted to analyze the degree of illness acceptance: gender, age, education level, place of residence, marital status, and occupational activity.

Table 6 presents results concerning the degree of acceptance of illness according to gender.

Females more often than males evaluated their level of illness acceptance in lower categories. In turn, males more frequently indicated a high degree of acceptance of the disease ( $>30$ scores), compared to females (58.5\% and $41.5 \%$, respectively). Data in Table 6 show that the differences in the degree of acceptance of illness according to gender were statistically insignificant ( $\mathrm{p}>0.05)$. 
Table 6. Degree of acceptance of hepatitis C illness according to respondents' gender

\begin{tabular}{lccccc}
\hline \multirow{2}{*}{ Gender } & & \multicolumn{3}{c}{ AlS result } & \multirow{2}{*}{ Total } \\
\cline { 2 - 5 } male & & $<20$ & $20-30$ & $>30$ & \\
\hline \multirow{2}{*}{ female } & $\mathrm{n}$ & 29 & 38 & 38 & 105 \\
\cline { 2 - 5 } & $\%$ & 46.0 & 41.3 & 58.5 & 47.7 \\
\hline \multirow{2}{*}{ Total } & $\mathrm{n}$ & 34 & 54 & 27 & 115 \\
\hline & $\%$ & 54.0 & 58.7 & 41.5 & 52.3 \\
\hline & $\mathrm{n}$ & 63 & 92 & 65 & 220 \\
\hline
\end{tabular}

Stat. $\left(\mathrm{Chi}^{2}\right) ;{ }^{\prime} \mathrm{p}^{\prime}$

$4.595923 ; p=0.10046$

Table 7. Assessment of the degree of acceptance of hepatitis C according to respondents' age

\begin{tabular}{|c|c|c|c|c|c|}
\hline \multirow{2}{*}{ Age (years) } & & \multicolumn{3}{|c|}{ AIS result } & \multirow{2}{*}{ Total } \\
\hline & & $<20$ & $20-30$ & $>30$ & \\
\hline \multirow{2}{*}{$18-49$} & $\mathrm{n}$ & 22 & 31 & 27 & 80 \\
\hline & $\%$ & 35.0 & 33.6 & 41.5 & 36.7 \\
\hline \multirow{2}{*}{$50-65$} & $\mathrm{n}$ & 25 & 40 & 24 & 89 \\
\hline & $\%$ & 39.6 & 43.5 & 37.0 & 40.5 \\
\hline \multirow{2}{*}{$66-87$} & $\mathrm{n}$ & 16 & 21 & 14 & 51 \\
\hline & $\%$ & 25.4 & 22.9 & 21.5 & 23.2 \\
\hline \multirow{2}{*}{ Total } & $\mathrm{n}$ & 63 & 92 & 65 & 220 \\
\hline & $\%$ & 28.7 & 41.8 & 29.5 & 100.0 \\
\hline
\end{tabular}

Stat. $\left(\mathrm{Chi}^{2}\right) ;{ }^{\prime}{ }^{\prime}$

$1.326501 ; p=0.85686$

Table 7 demonstrates data concerning the degree of acceptance of hepatitis $\mathrm{C}$ according to respondents' age.

In the subpopulation of respondents who evaluated their degree of acceptance of the illness in a low category ( $<20$ scores) the number of the examined patients in each selected age group was at least one-fourth, with the highest percentage of those aged 50-65 (39.6\%). Among respondents who evaluated their illness acceptance to be at the mean degree (20-30 scores), the highest percentage were those aged 50-65 (43.5\%). Among patients who reported a high level of acceptance of $\mathrm{HCV}$ infection ( $>30$ scores), the highest percentage were the youngest respondents aged $18-49-41.5 \%$. The older the age group, the lower the percentage of respondents who evaluated their acceptance of illness in the highest category. Analysis of data concerning the acceptance of hepatitis $C$ illness according to age did not show any significant relationships ( $p>0.05$ ).

Table 8 presents analysis of the degree of acceptance of illness according to the education level of patients infected with HCV (Tab. 8).

Nearly a half of respondents (49.2\%) who reported the degree of acceptance of their illness on the lowest threshold of scores ( $<20$ scores) had primary vocational education. Among respondents who accepted their illness to a mean degree (20-30 scores), the highest percentage were those with secondary school education (45.6\%). Patients with secondary school education (33.9\%) and those with primary vocational education (32.3\%) nearly equally frequently reported a high level of acceptance of infection with HCV. No statistically significant differences were found ( $p>0.05$ ).

Analysis of the collected research material included also the degree of acceptance of illness according to place of residence (Tab. 9).
Table 8. Assessment of the degree of acceptance of hepatitis $C$ according to respondents' education level

\begin{tabular}{|c|c|c|c|c|c|}
\hline \multirow{2}{*}{ Education level } & & \multicolumn{3}{|c|}{ AIS result } & \multirow{2}{*}{ Total } \\
\hline & & $<20$ & $20-30$ & $>30$ & \\
\hline \multirow{2}{*}{ primary school } & $\mathrm{n}$ & 6 & 8 & 7 & 21 \\
\hline & $\%$ & 9.5 & 8.7 & 10.8 & 9.5 \\
\hline \multirow{2}{*}{ primary vocational } & $\mathrm{n}$ & 31 & 32 & 21 & 84 \\
\hline & $\%$ & 49.2 & 34.8 & 32.3 & 38.2 \\
\hline \multirow{2}{*}{ secondary school } & $\mathrm{n}$ & 18 & 42 & 22 & 82 \\
\hline & $\%$ & 28.6 & 45.6 & 33.9 & 37.3 \\
\hline \multirow{2}{*}{ higher } & $\mathrm{n}$ & 8 & 10 & 15 & 33 \\
\hline & $\%$ & 12.7 & 10.9 & 23.0 & 15.0 \\
\hline \multirow{2}{*}{ Total } & $\mathrm{n}$ & 63 & 92 & 65 & 220 \\
\hline & $\%$ & 28.7 & 41.8 & 29.5 & 100.0 \\
\hline Stat. $\left(\mathrm{Chi}^{2}\right) ;{ }^{\prime} p^{\prime}$ & & \multicolumn{3}{|c|}{$1.326501 ; p=0.85686$} & - \\
\hline
\end{tabular}

Table 9. Assessment of the degree of acceptance of hepatitis C according to respondents' place of residence

\begin{tabular}{|c|c|c|c|c|c|c|c|c|c|}
\hline $\begin{array}{l}\text { Place of } \\
\text { residence }\end{array}$ & $\mathrm{N}$ & $\%$ & $M^{*}$ & $\mathrm{SD}^{*}$ & $\mathrm{Me}^{*}$ & Min.* & Max.* & $\begin{array}{c}\text { Z } \\
\text { Mann- } \\
\text { Whitney } \\
\text { U test }\end{array}$ & $p$ \\
\hline rural area & 73 & 33.2 & 23.2 & 7.1 & 22.0 & 10.0 & 40.0 & \multirow{2}{*}{$Z=-2.59$} & \multirow{2}{*}{0.01} \\
\hline urban area & 147 & 66.8 & 26.2 & 8.8 & 25.0 & 8.0 & 40.0 & & \\
\hline
\end{tabular}

Considering the fact that the independent variable had 2 samples (urban and rural inhabitants) Mann-Whitney U test was applied. Table 9 and Figure 1 demonstrate the results.

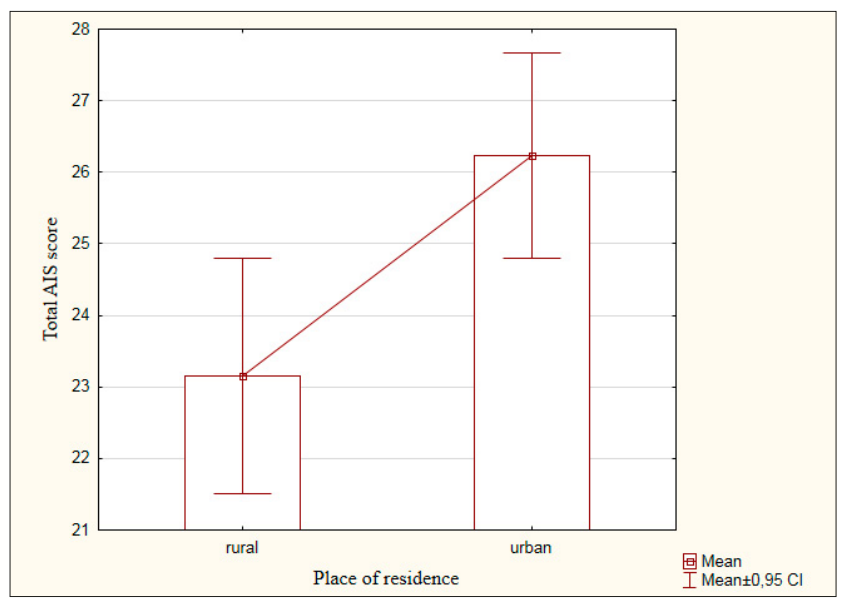

Figure 1. Degree of acceptance of hepatitis C according to respondents' place of residence

Table 9 shows that the majority of respondents were urban inhabitants (66.8\%); mean AIS score - 26.2.

Statistical analysis confirmed that respondents who lived in urban areas showed significantly statistically higher degree of illness acceptance, compared to rural inhabitants $(\mathrm{Z}=-2.59$; $\mathrm{p}<0.01)$.

While assessing the degree of acceptance of illness an independent variable of marital status was also considered (Tab. 10).

It was confirmed that among respondents who indicated a low degree of acceptance of the disease ( $<20$ scores), the 
Table 10. Assessment of the degree of acceptance of hepatitis $C$ according to marital status

\begin{tabular}{|c|c|c|c|c|c|}
\hline \multirow{2}{*}{ Marital status } & & \multicolumn{3}{|c|}{ AIS result } & \multirow{2}{*}{ Total } \\
\hline & & $<20$ & $20-30$ & $>30$ & \\
\hline \multirow{2}{*}{ never married } & $\mathrm{n}$ & 6 & 18 & 16 & 40 \\
\hline & $\%$ & 9.5 & 19.6 & 24.6 & 18.2 \\
\hline \multirow{2}{*}{ married } & $\mathrm{n}$ & 30 & 44 & 35 & 109 \\
\hline & $\%$ & 47.6 & 47.8 & 53.9 & 49.5 \\
\hline \multirow{2}{*}{ divorced } & $\mathrm{n}$ & 11 & 16 & 3 & 30 \\
\hline & $\%$ & 17.5 & 17.4 & 4.6 & 13.6 \\
\hline \multirow{2}{*}{ widowed } & $\mathrm{n}$ & 16 & 14 & 11 & 41 \\
\hline & $\%$ & 25.4 & 15.2 & 16.9 & 18.6 \\
\hline \multirow{2}{*}{ Total } & $\mathrm{n}$ & 63 & 92 & 65 & 220 \\
\hline & $\%$ & 28.7 & 41.8 & 29.5 & 100.0 \\
\hline Stat. $\left(\mathrm{Chi}^{2}\right) ;{ }^{\prime} p^{\prime}$ & & \multicolumn{3}{|c|}{$12.42140 ; p=0.13337$} & - \\
\hline
\end{tabular}

largest group were those in the category 'married' (47.6\%). Similarly, among respondents who mentioned the mean degree of illness acceptance (20-30 scores) the largest percentage were those in a marital relationship (47.8\%). Also, the majority of respondents who reported a high degree of acceptance of illness ( $>30$ scores) were married (53.9\%). The results were statistically insignificant $(\mathrm{p}>0.05)$.

Acceptance of the illness was also assessed according to respondents' occupational activity. The results were analysed using Mann-Whitney U test, and presented in Table 11 and Figure 2.

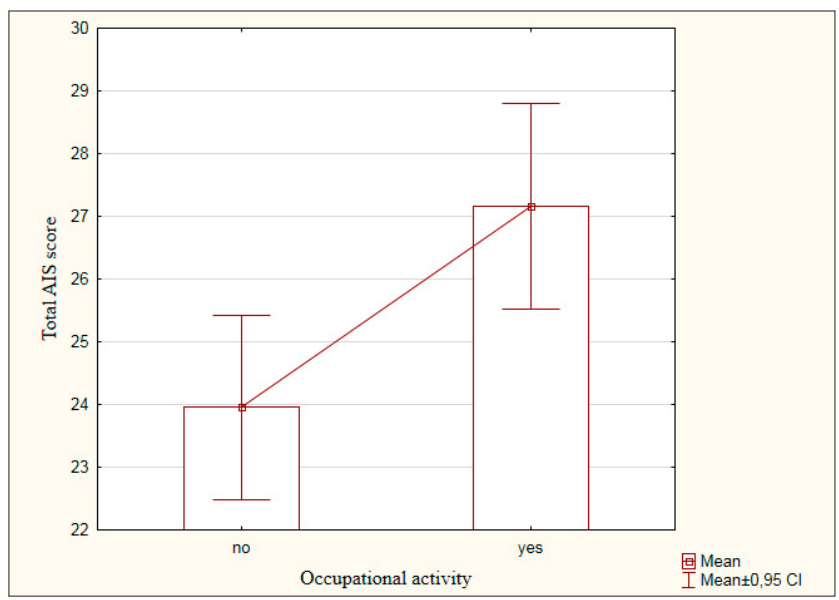

Figure 2. Degree of acceptance of hepatitis $C$ according to respondents' occupational activity

Table 11. Assessment of the degree of acceptance of hepatitis $\mathrm{C}$ according to respondents' occupational activity

\begin{tabular}{|c|c|c|c|c|c|c|c|c|c|}
\hline $\begin{array}{l}\text { Occupational } \\
\text { activity }\end{array}$ & $\mathrm{N}$ & $\%$ & $M^{*}$ & $S D^{*}$ & $M e^{*}$ & Min.* & Max.* & $\begin{array}{c}\text { Z } \\
\text { Mann- } \\
\text { Whitney } \\
\text { U test }\end{array}$ & $p$ \\
\hline Yes & 86 & 39.1 & 27.2 & 7.6 & 25.0 & 10.0 & 40.0 & \multirow{2}{*}{$Z=-2.76$} & \multirow{2}{*}{0.01} \\
\hline No & 134 & 60.9 & 24.0 & 8.6 & 23,0 & 8.0 & 40.0 & & \\
\hline
\end{tabular}

${ }^{*} \mathrm{M}$ - mean; SD - standard deviation; Me - median; I Min -Max - minimum-maximum

It was confirmed that a large number of respondents with hepatitis $\mathrm{C}$ were not occupationally active (60.9\%); mean AIS score - 24.0.
Statistical analysis demonstrated that respondents who were occupationally active, despite hepatitis $\mathrm{C}$, manifested a significantly higher level of illness acceptance, compared to those who were occupationally inactive -27.2 vs. 24.0 scores, respectively, $\mathrm{p}<0.01$ - result of Mann-Whitney $U$ test $(\mathrm{Z}=-2.76)$.

While analysing the degree of acceptance of illness, selfreported state of health was also taken into consideration, according to evaluation categories: very good, good, mediocre, poor, and very poor.

Relationships between self-reported state of health and degree of acceptance of hepatitis C measured by the AIS were analyzed using Spearman's rank correlation coefficient, and presented in Table 12, while Figure 3 demonstrates the results.

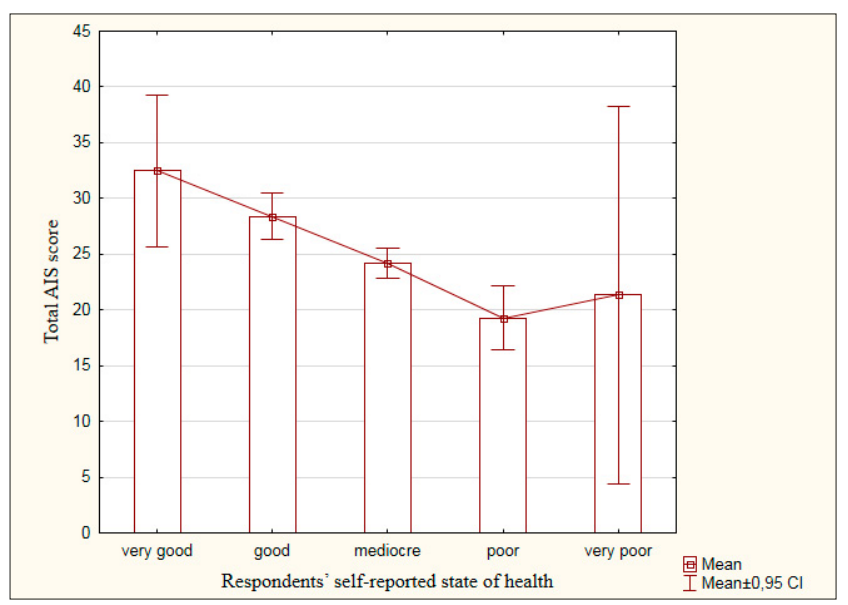

Figure 3. Degree of acceptance of hepatitis $C$ according to respondents' selfreported state of health

Table 12. Degree of acceptance of hepatitis $C$ according to respondents' self-reported state of health

\begin{tabular}{|c|c|c|c|c|c|c|c|c|c|}
\hline $\begin{array}{l}\text { Self reported } \\
\text { state of health }\end{array}$ & $\mathrm{N}$ & $\%$ & $M^{*}$ & $S D^{*}$ & $\mathrm{Me}^{*}$ & Min.* & Max.* & $\begin{array}{l}\text { Spearman's } \\
\text { rho }\end{array}$ & $p$ \\
\hline very good & 8 & 3.6 & 32.5 & 8.1 & 34.0 & 18.0 & 40.0 & \multirow{5}{*}{$R=-0.36$} & \multirow{5}{*}{0.00} \\
\hline good & 70 & 31.8 & 28.4 & 8.9 & 29.0 & 10.0 & 40.0 & & \\
\hline mediocre & 112 & 50.9 & 24.2 & 7.2 & 24.0 & 8.0 & 40.0 & & \\
\hline poor & 27 & 12.3 & 19.3 & 7.2 & 17.0 & 8.0 & 36.0 & & \\
\hline very poor & 3 & 1.4 & 21.3 & 6.8 & 19.0 & 16.0 & 29.0 & & \\
\hline
\end{tabular}

${ }^{*} \mathrm{M}$ - mean; SD - standard deviation; Me - median; Min-Max - minimum-maximum

The highest percentage of respondents evaluated their state of health as mediocre 50.9\%; mean AIS score - 24.2. The lowest score in this group was 8 (low degree of acceptance of illness), whereas the highest - 40 scores (high degree of acceptance of illness); median - 24.2. It was confirmed that the lower the self-reported health, the significantly lower degree of illness acceptance $(\mathrm{p}<0.05)$ - negative correlation coefficient $(\mathrm{R}=-0.36)$.

Table 13 contains data concerning the assessment of the degree of acceptance of hepatitis $\mathrm{C}$ according to whether or not a given respondent considered himself/herself as disabled.

Relationships between the degree of acceptance of hepatitis $\mathrm{C}$ measured by the AIS and the feeling of being disabled were analyzed using the Mann-Whitney $U$ test, and presented in Table 13, while Figure 4 demonstrates their distribution. 


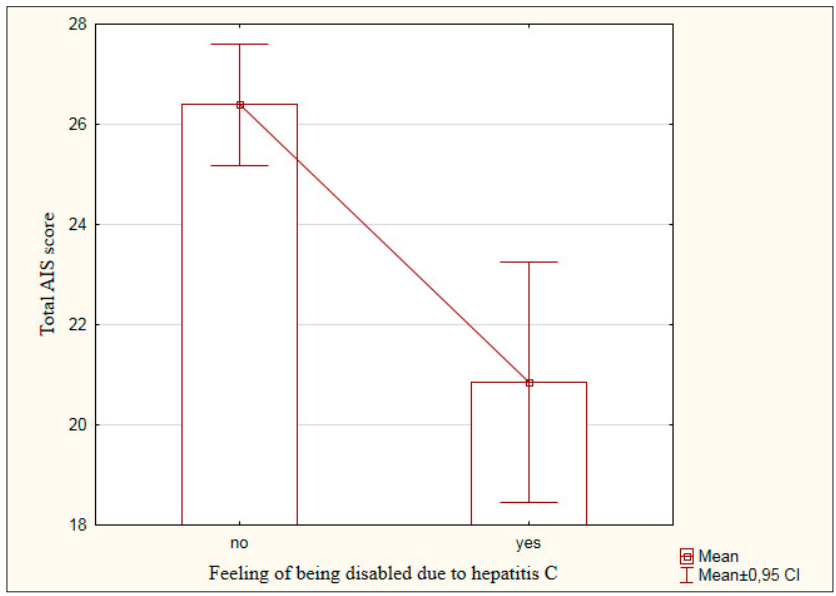

Figure 4. Degree of acceptance of hepatitis $C$ according to respondents' feeling of being disabled

Table 13. Degree of acceptance of hepatitis C according to respondents' feeling of being disabled

\begin{tabular}{|c|c|c|c|c|c|c|c|c|c|}
\hline $\begin{array}{l}\text { Feeling } \\
\text { of being } \\
\text { disabled }\end{array}$ & $\mathrm{N}$ & $\%$ & $M^{*}$ & $S D^{*}$ & $\mathrm{Me}^{*}$ & Min.* & Max.* & $\begin{array}{c}\text { Z } \\
\text { Mann-Whitney } \\
\text { U test }\end{array}$ & $p$ \\
\hline Yes & 47 & 21.4 & 26.4 & 8.0 & 25.0 & 8.0 & 40.0 & \multirow{2}{*}{$Z=4.18$} & \multirow{2}{*}{0.00} \\
\hline No & 173 & 78.6 & 20.9 & 8.1 & 19.0 & 8.0 & 40.0 & & \\
\hline
\end{tabular}

*M - mean; SD - standard deviation; Me - median; Min-Max - minimum-maximum

It was found that the majority of respondents in the examined group did not consider themselves as disabled due to hepatitis C (78.6\%); mean AIS score - 20.9.

Statistical analysis confirmed that the respondents who did not consider themselves disabled showed a significantly higher degree of acceptance of their illness, compared to those who regarded themselves as disabled (26.4 vs. 20.9 scores), $\mathrm{p}<0.05$ - result of Mann-Whitney $\mathrm{U}$ test $(\mathrm{Z}=4.18)$.

\section{DISCUSSION}

In Poland, hepatitis $\mathrm{C}$ is a serious epidemiological problem. Each year, up to 4,000 infections with hepatitis $C$ virus are noted, and many people are unaware that they have contracted the disease. Therefore, it is necessary to constantly develop new prophylactic actions, which would allow both the detection and limitation of the number of cases of hepatitis C. Apart from treatment and rehabilitation problems, the problem of acceptance of the illness is extremely important.

Acceptance of chronic hepatitis $\mathrm{C}$ is the recognition by a person infected with HCV of own, limited psycho-physical abilities, and working out in this situation an appropriate attitude towards oneself, as well as towards own social and physical environment. According to the team of researchers directed by Grochans et al., males more frequently (59.5\%) expect support on the part of the external environment. Disturbed social relationships are more often indicated by persons with the lowest education level (74.7\%) [22]. The results of own study confirmed that respondents with the lowest level of education reported the lowest degree of acceptance of their illness ( $\mathrm{p}>0.05)$.

A team of researchers (Barański, Szuba, Cena OlszaneckaGlinianowicz et al.) found that problems of a social nature considerably decrease the quality of life of females infected with HCV, who more often suffer from social stigmatization [23]. Own study demonstrated that females, more frequently than males, reported a low level of acceptance of their illness ( $\mathrm{p}>0.05)$.

Acceptance of a chronic gastrointestinal disease by a patient means learning to live with complaints, with dietary limitations, and use own positive qualities and opportunities. The frequent problem for people with a chronic disease is that they cannot come to terms with their difficult situation and accept their state of health. Zickmund et al. confirmed that a decrease in the quality of life of persons infected with $\mathrm{HCV}$ is conditioned by problems of communication with the consulting physician (28\%), lack of competences of a physician in the diagnosis and treatment (23\%), or stigmatization by a physician (9\%) [24]. Few persons with hepatitis $\mathrm{C}$ in own study indicated problems with access to a physician (5.3\%).

Deterioration of the quality of life of patients infected with HCV is often caused by unemployment, concomitant diseases, low performance at work, loss of employment, and difficulties with fulfilling social roles [25, 26, 27, 28].

In systematic literature reviews reports are encountered concerning studies of the quality of life of people infected with HCV [29, 30, 31]; however, the results pertaining to the degree of acceptance of hepatitis $C$ have not been found.

According to the team of researchers (Alves, Baldessar, Wrublevski Pereira et al.) the general state of health and well-being of patients with hepatitis C in Brazil were negatively affected by: lower education level, unemployment, concomitant diseases (diabetes, arterial hypertension, chronic renal disease, overweight), and an individual perception of progression of the disease [29]. Similar results of studies among patients with hepatitis $\mathrm{C}$ were obtained from 3 centres in France - a lower level of the quality of life of patients and the feeling of fatigue were determined by such variables as: lack of employment, severe concomitant diseases, overweight, and concern about the progression of the disease [30]. Own study demonstrated that adults infected with HCV most often reported the mean degree of acceptance of their illness (20-30 scores) $-41.8 \%$ of respondents. The second group were respondents infected with HCV who mentioned a high degree of acceptance of their illness ( $>30$ scores) $29.5 \%$, followed by those who accepted their illness to a low degree or not at all ( $<20$ scores $)-28.6 \%$. The results obtained confirmed that with respect to the majority of statements the respondents' answers did not differ according to gender, age, education level, and marital status $(\mathrm{p}>0.05)$. A significant statistical difference concerned acceptance of illness ( $>30$ scores) by respondents living in urban areas, compared to rural inhabitants $(\mathrm{p}<0.05)$. In turn, a low degree or lack of acceptance of hepatitis C ( $<20$ scores) significantly more often occurred among respondents who were occupationally inactive, and maintained themselves on a disability or retirement pension, or had the status of an unemployed person $(\mathrm{p}<0.05)$. Apart from this, own study indicated that the lower the respondents' self-reported state of health, the significantly lower the degree of their acceptance of illness $(\mathrm{p}<0.05 ; \mathrm{R}=-0.36)$. It was also confirmed that the majority of respondents $(78,6 \%)$ who did not consider themselves disabled, despite hepatitis $\mathrm{C}$, reported a significantly higher degree of acceptance of their illness, compared to those who regarded themselves as disabled $(\mathrm{p}<0.05 ; \mathrm{Z}=4.18)$. 
Huang, Rao, Shang et al. examined Chinese patients infected with HCV and found that the lower quality of life of this group of patients depended on discomfort due to severe symptoms of the disease, its progression, and depressive symptoms [31]. A study concerning the quality of life of patients with hepatitis C carried out in Spain by López, Seiz, Portales et al., demonstrated that patients with a long-lasting, asymptomatic disease showed a lower quality of life [32]. Own study confirmed that a low degree of acceptance of chronic hepatitis $\mathrm{C}(<20$ scores) was most frequently indicated by patients aged $66-87$ ( $p>0.05)$, and those who had been ill for $11-20$ years and more than 20 years $(\mathrm{p}>0.05)$.

Despite various complaints associated with hepatitis $\mathrm{C}$, persons infected with $\mathrm{HCV}$ accepted the fact of being ill mainly to the mean degree, while $29.5 \%$ of respondents - to a high degree. Considering the fact that approximately onethird of respondents accepted their illness to a low degree or did not accept it at all, these persons require support from specialists in their daily life, best within a programme of long-term individually planned rehabilitation. An effective support by a psychologist, who is the member of the rehabilitation team, is a great chance for improving the quality of life of patients with hepatitis $\mathrm{C}$ in each domain of life, i.e. physical, psychological, and social. Every level of support provided for a patient may, and frequently does translate into a higher degree of acceptance of a chronic illness, such as hepatitis C.

\section{CONCLUSIONS}

According to the AIS, nearly a half of respondents accepted their illness to the mean degree, whereas a high and low degree of acceptance concerned the same groups of respondents.

No significant relationships were found between the degree of acceptance of illness by patients with chronic hepatitis $\mathrm{C}$, according to gender, age, education level, and marital status, whereas significant differences were observed according to the place of residence and the feeling of being a disabled person. Urban inhabitants more often reported a high degree of acceptance of their illness, compared to rural inhabitants, and respondents who did not consider themselves disabled due to hepatitis $\mathrm{C}$ indicated a significantly higher degree of acceptance of illness, compared to those who regarded themselves as disabled.

Low degree or lack of acceptance of hepatitis C was significantly more frequently observed in patients who were occupationally inactive and, at the same time, presented a lower self-reported state of health.

The results of the study confirm the need for providing psychological assistance for patients with hepatitis $\mathrm{C}$, in order to support them in, among other things, the skills of selecting pro-health behaviours, change in the way of perception and evaluation of own health situation, as well as evaluation of the degree of illness acceptance in higher AIS categories.

\section{REFERENCES}

1. Zakrzewska K, Szmulik K, Stępień M, et al. Wirusowe zapalenie wątroby typu C w Polsce w 2015 roku. Przegl Epidemiol. 2017; 71(3): 363-371.

2. Zakrzewska K, Stępień M, Rosińsk M. Wirusowe zapalenie wątroby typu C (wzw C) w Polsce w 2017 roku. Przegl Epidemiol. 2019; 73(2): 167-178. https://doi.org/10.32394/pe.73.16
3. Pokorska-Śpiewak M, Śpiewak M. Management of hepatitis C in children and adolescents during COVID-19 pandemic. World J Hepatol. 2020; 12(8): 485-492. https://doi.org/10.4254/wjh.v12.i8.485

4. Kamili S, Drobeniuc J, Araujo AC, et al. Laboratory diagnostics for hepatitis C virus infection. Clin Infect Dis. 2012; 55(1): 43-48, https:// doi.org/10.1093/cid/cis368

5. Sierpińska L. Hepatitis C as a health problem in Poland. J Nurs Care. 2015; 1(1): 1-5.

6. Hashim AE, Zaky S, Azab N, et al. Peripheral blood mononuclear cells hepatitis $\mathrm{C}$ virus RNA as a predictor for the response to daclatasvircontaining oral antiviral regimen in chronic hepatitis $\mathrm{C}$ patients for the Damietta. Al-Azhar Assiut Med J. 2019; 17(1): 9-13, https://doi. org/10.4103/AZMJ.AZMJ_78_18

7. Halota W, Flisiak R, Boroń-Kaczmarska A, et al. Recommendations for the treatment of hepatitis $\mathrm{C}$ issued by the Polish Group of HCV Experts - 2016. J Clin Exp Hepatol. 2016; 2: 27-33. https://doi.org/10.5114/ ceh.2016.59099

8. Stępień M, Rosińska M. Ogniska wirusowego zapalenia wątroby typu C w Polsce w latach 2003-2013. Procedury medyczne najczęstszą drogą przenoszenia zakażeń HCV. Przegl Epidemiol. 2015; 69(3): 585-590.

9. Sakem B, Madaliński K, Nydegger U, et al. Hepatitis C virus epidemiology and prevention in Polish and Swiss population - similar and contrasting experiences. Ann Agric Environ Med. 2016; 23(3): 425-431. https://doi.org/10.5604/12321966.1219181

10. Ziółkowski A, Błachnio A, Pąchalska M. Ocena zadowolenia z życia i zdrowia - Jakość życia seniorów. Ann Agric Environ Med. 2015; 22(1): 147-151. https://doi.org/10.5604/12321966.1141385

11. Tomasiewicz K. Kiciak S, Murias-Bryłowska E. Współczesne poglądy na zagadnienie możliwości transmisji wirusa zapalenia wątroby typu C w placówkach opieki medycznej. Hepatology 2015; 15: 60-64. https:// doi: 10.5114/hepatologia. 2015. 51781

12. Nguyen DB, Bixler D. Patel PR. Transmission of hepatitis C virus in the dialysis setting and strategies for its prevention. Semin Dial. 2019; 32(2): 127-134. https://doi.org/10.1111/sdi.12761

13. Grabarczyk P, Medyńska J, Liszewski G, et al. HCV RNA and HIV RNA detection by Procleix HIV-1/ /HCV Assay in blood donors with various results of anti-HCV and anti-HIV EIA. J Transf Med. 2009; 1(1): 26-33.

14. Cooke GS, Andrieus-Meyer I, Applegate TL, et al. Accelerating the elimination of viral hepatitis. Lancet Gastroenterol Hepatol. 2019; 4: 135-184. https://doi.org/10.1016/s2468-1253(18)30270-x

15. Axley P, Ahmed Z, Ravi S, et al. Hepatitis C Virus and Hepatocellular Carcinoma: A Narrative Review. J Clin Transl Hepatol. 2018; 6: 79-84. https://doi.org/10.14218/JCTH.2017.00067

16. Marinho RT, Barreira DP. Hepatitis C, stigma and cure. World J Gastroenterol. 2013; 19: 6703-6709. https://doi.org/10.3748/wjg.v19. i40.6703

17. Mui UN, Haley ChT, Tyring SK. Viral oncology: molecular biology and pathogenesis. J Clin Med. 2017; 6-12: 111. https://doi.org/10.3390/ jcm6120111

18. Bosetti C, Turati F, La Vecchia C. Hepatocellular carcinoma epidemiology. Best Pract Res Clin Gastroenterol. 2014; 28(5): 753-770, https://doi.org/10.1016/j.bpg.2014.08.007

19. Muzica CM, Stanciu C, Anca Tri A, et al. Hepatocellular carcinoma after direct-acting antiviral hepatitis $\mathrm{C}$ virus therapy: A debate near the end. Word J Gastroenterol. 2020; 26(43): 6770-6781. https://doi. org/10.3748/wjg.v26.i43.6770

20. Sierpińska L. Narzędzia pomiaru jakości życia zakażonych wirusem HCV. J Educ Health Sport. 2017; 7(5): 185-196. http://dx.doi.org/10.5281/ zenodo. 573094

21. Felton BJ, Revension TA, Hionrichsen GA. (adaptacja Juczyński Z.). Skala akceptacji choroby AIS. In: Juczyński Z. Narzędzia pomiaru w promocji psychologii zdrowia. Warszawa: Pracownia Testów Psychologicznych; 2009. p. 162-166.

22. Grochans E, Sychta D, Szkup M, reditor. Ocena relacji społecznych i środowiskowych pacjentów z przewlekłym wirusowym zapaleniem wątroby typu C. Probl Hig Epidemiol. 2010; 91(1): 131-136.

23. Barański K, Szuba E, Olszanecka-Glinianowicz M, et al. Czynniki socjodemograficzne wpływające na poziom wiedzy dotyczącej dróg szerzenia się zakażenia w kontaktach niezwiązanych z procedurami medycznymi wśród pacjentów z WZW typu C. Ann Acad Med Siles. 2013; 67(5): 294-302.

24. Zickmund S, Hillis SL, Barnett MJ, et al. Hepatitis C virus-infected patients report communications problems with physicians. Hepatology. 2004; 39(4): 999-1007. https://doi.org/10.1002/hep.20132

25. El-Serag HB, Kanwal F, Richardson P, et al. Risk of hepatocellular carcinoma after sustained virological response in Veterans with 
hepatitis C virus infection. Hepatology. 2016; 64(1): 130-137. https:// doi.org/10.1002/hep. 28535

26. Hoshida Y, Fuchs BC, Bardeesy N, et al. Pathogenesis and prevention of hepatitis C virus-induced hepatocellular carcinoma. J Hepatol. 2014 61(1 Suppl): 79-90. https://doi.org/10.1016/j.jhep.2014.07.010

27. Cardoso H, Silva M. Health-related quality of life in chronic hepatitis C. GE Port J Gastroenterol. 2017; 24(2): 55-57. https://doi. org $/ 10.1159 / 000453319$

28. Barreira DP, Marinho RT, Bicho M, et al. Psychosocial and neurocognitive factors associated with hepatitis $\mathrm{C}$ - implications for future health and wellbeing. Front Psychol. 2018; 9(2666): 1-6. https:// doi.org/10.3389/fpsyg.2018.02666
29. Cardoso H, Silva M. Health-Related Quality of Life in Chronic Hepatitis C. GE Port 2017; 24(2): 55-57. https://doi.org/10.1159/000453319

30. Cossais S, Schwarzinger M, Pol S, et al. Quality of life in patients with chronic hepatitis $\mathrm{C}$ infection: Severe comorbidities and disease perception matter more than liver-disease stage. PLoS One 3 May 2019; 14(5): e0215596. https://doi.org/10.1371/journal.pone.0215596

31. Huang R, Rao H, Shang J, et al. A cross-sectional assessment of healthrelated quality of life in Chinese patients with chronic hepatitis $\mathrm{c}$ virus infection with EQ-5D. Health Qual Life Outcomes. 2018; 16(1): 124. https://doi.org/10.1186/s12955-018-0941-8

32. López RH, Seiz AM, Portales MR, et al. Estudio de calidad de vida en pacient asasintomáticos con hepatitis C. Rev Esp Enferm Dig. 2020; 112(7): 520-524. https://doi.org/10.17235/reed.2019.6339/2019 